\title{
PENGARUH TEKNIK RELAKSASI TERHADAP PENURUNAN SKALA NYERI POST OPERASI DI RUMAH SAKIT Dr.OEN SURAKARTA
}

\author{
Oleh : \\ Diyono ${ }^{1}$ Sriyani Mugiarsih ${ }^{2}$ Budi Herminto ${ }^{3}$
}

\begin{abstract}
Background. Pain is an unpleasant sensory and emotional experience associated with actual or potensial tissue damage or describe in termis of such damage. One of many factor caused pain was surgery. Relaxation technique is one nonpharmacological intervention to reduce pain in patients with post operative.

Purpose. This study was to determine the effect of relaxation technique to reduce pain on patients post operative at Dr.Oen Solo Baru hospital.

Method. This study used pre and post experiment design. The sampling technique used consecutive sampling wth total number subject of sampling were 25 patients. The pain scale was measured before and after intervention. Data was analyzed by paired t-test statistical test with significance level $\alpha 0.05$ and the degree of permanence (dk) : 24

Conclusion The result shoed $t: 2.064$ means that $t$ count $>t$ table (7.855>2.064). it can be concluded that relaxation technique can reduce pain on patients post operative at Dr.Oen Solo Baru Hospital.
\end{abstract}

Keywords : Relaxation Techniques, Pain Scale, Post Operative

\section{PENDAHULUAN}

Nyeri adalah perasaan tidak nyaman yang bersifat subjektif dimana hanya orang yang mengalaminya yang dapat menjelaskan dan mengevaluasi perasaan tersebut. (Mubarak, 2007) Nyeri dapat disebabkan beberapa faktor yang salah satunya adalah pembedahan. Pembedahan yang dilakukan pada seorang pasien akan menimbulkan ansietas, rasa takut, nyeri dan ketidaknyamanan. Pemberitahuan informasi yang bermanfaat dapat menenangan pasien, mengurangi rasa takut dan menyiapkan pikiran pasien untuk pengalaman tersebut. Setelah pasien pasca-operasi biasanya merasakan ketidaknyamanan eksternal bagi pasien. Nyeri juga memperlambat pemulihan dan dapat menimbulkan komplikasi.
Banyak intervensi atau tindakan keperawatan nonfarmakologis yang dapat membantu menurunkan atau bahkan menghilangkan nyeri, termasuk nyeri paska operasi. Intervensi tersebut diantaranya adalah teknik relaksasi. Relaksasi dipercaya dapat menurunkan nyeri dengan merelaksasikan ketegangan otot yang mendukung rasa nyeri. Teknik relaksasi mungkin perlu diajarkan beberapa kali agar mencapai hasil optimal. Dengan relaksasi pasien dapat mengubah persepsi terhadap nyeri.

Dalam kenyataan di lapangan atau klinik, penggunaan teknik relaksasi jarang dilakukan dan lebih mengedepankan aspek farmakologis dalam penanganan nyeri. Padahal dari laporan-laporan yang sudah dilakukan sebelumnya penggunaan teknik relaksasi diketahui cukup efektif untuk menurunkan nyeri pada 
pasien post operasi. Berdasarkan pada penelitian hipotesa tersebut maka peneliti tertarik untuk melakukan penelitian tentang pengaruh tehnik relaksasi terhadap skala nyeri pada pasien post operasi di RS Dr. Oen Solo Baru.

\section{METODE PENELITIAN}

Penelitian ini merupakan penelitian eksperimen dengan rancangan Pre Post Experimental. Model rancangan ini mengungkapkan hubungan sebab akibat dengan cara melibatkan satu kelompok subjek. (Hidayat, 2003) Peneliti akan melakukan pre test dan post test tentang perbedaan nyeri pada pasien post operasi sebelum dan sesudah diajarkan teknik relaksasi.

Populasi dari penelitian ini adalah pasien post operasi di bangsal Tjan Barat dan Tjan Timur di RS Dr.Oen Solo Baru. Dari studi pendahuluan diperoleh rata-rata pasien operasi dalam 1 bulan sebanyak 40 orang. Karena keterbatasan peneliti maka peneliti mengambil sampel sebanyak 25 responden dengan kriteria inklusi adalah pasien yang bersedia menjadi responden, post operasi hari I - II, kesadaran kompos mentis, tidak ada gangguan persepsi sensori.

Pengambilan sampel dilakukan dengan teknik Consecutive Sampling, yaitu cara pengambilan sampel dengan memilih sampel yang memenuhi kriteria penelitian sampai kurun waktu tertentu sehingga jumlah sampel terpenuhi. (Hidayat, 2003)

Pengumpulan data dimulai dengan peneliti datang ke pasien yang memenuhi kriteria inklusi, kemudian diukur skala nyeri yang dirasakan. Setelah itu peneliti mengajarkan teknik relaksasi sampai pasien betul - betul paham. Selanjutnya peneliti meminta pasien melakukan teknik relaksasi secara mandiri atau dengan bimbingan keluarga setiap merasakan nyeri dan kemudian diukur skala nyerinya.

\section{HASIL PENELITIAN}

Dari penelitian yang dilakukan oleh peneliti tentang pengaruh teknik relaksasi terhadap penurunan skala nyeri post operasi di rumah sakit Dr.Oen Solo Baru dilakukan secara eksperimental didapatkan dalam bentuk tabel sebagai berikut :

Tabel 1. Distribusi frekuensi responden menurut umur

\begin{tabular}{c|c|c}
\hline $\begin{array}{c}\text { Kelompok } \\
\text { Umur }\end{array}$ & Frekuensi & Prosentase \\
\hline$<25$ & 4 & 16 \\
$25-40$ & 8 & 32 \\
$>45$ & 13 & 52 \\
\hline Total & 25 & 100 \\
\hline
\end{tabular}

Berdasarkan tabel di atas didapatkan hasil, responden paling banyak berumur diantara >45 (52\%), dan yang paling sedikit berumur $<25$ $(16 \%)$

Tabel 2. Distribusi frekuensi karakteristik responden berdasar jenis kelamin

\begin{tabular}{ccc}
\hline $\begin{array}{c}\text { Jenis } \\
\text { Kelamin }\end{array}$ & Frekuensi & Prosentase \\
\hline Laki-laki & 14 & 56 \\
Perempuan & 11 & 44 \\
\hline Total & 25 & 100 \\
\hline Berasarkan
\end{tabular}

Berdasarkan tabel di atas didapatkan hasil yang menjadi responden yang paling banyak berjenis kelamin lakilaki $(56 \%)$

Tabel 3. Distribusi frekuensi karakteristik responden berdasar tingkat pendidikan

\begin{tabular}{ccc}
\hline $\begin{array}{c}\text { Tingkat } \\
\text { Pendidikan }\end{array}$ & Frekuensi & Prosentase \\
\hline SD & 9 & 36 \\
SMP & 0 & 0 \\
\hline SMA & 9 & 36 \\
\hline D3 & 3 & 12 \\
\hline S1 & 4 & 16 \\
\hline Total & 25 & 100 \\
\hline
\end{tabular}

Berdasar tabel di atas didapatkan hasil responden sama besar tingkat 
pendidikan SMA dan SMP (36\%), sedangkan paling rendah D3 (12\%)

Tabel 4. Skala nyeri sesudah dilakukan teknik relaksasi

\begin{tabular}{ccc}
\hline Skala Nyeri & Frekuensi & Prosentase \\
\hline Tetap & 6 & 24 \\
Menurun & 19 & 76 \\
\hline Total & 25 & 100 \\
\hline
\end{tabular}

Berdasarkan tabel di atas di dapatkan hasil sesudah teknik relaksasi yang dilakukan di rumah sakit Dr.Oen Solo Baru yang paling banyak yaitu menurun (76\%)

Tabel 5. Skala nyeri sebelum dan sesudah dilakukan teknik relaksasi

\begin{tabular}{ccc}
\hline \multirow{2}{*}{ Nilai } & \multicolumn{2}{c}{ Skala Nyeri } \\
\cline { 2 - 3 } & $\begin{array}{c}\text { Sebelum } \\
\text { Relaksasi }\end{array}$ & $\begin{array}{c}\text { Sesudah } \\
\text { Relaksasi }\end{array}$ \\
\hline Mean & 7,84 & 5,92 \\
$\begin{array}{c}\text { Skala } \\
\text { Tertingi } \\
\text { Skala } \\
\text { Terendah }\end{array}$ & 9 & 9 \\
\hline
\end{tabular}

Berdasarkan tabel di atas didapatkan hasil rata-rata skala nyeri sebelum teknik relaksasi 7,84 dan sesudah teknik relaksasi 5,92. Jadi penurunan rata-rata skala nyeri sebelum teknik relaksasi dan sesudah teknik relaksasi 1,92. Kesimpulan sementara rata-rata sebelum teknik relaksasi lebih besar dari pada sesudah teknik relaksasi. Sedangkan dari hasil penghitungan rumus uji paire $t$ test didapatkan hasil nilai $t$ sebesar 7,855.

Hasil ini dikonversikan dengan t tabel dengan derajat kebebasan (dk) sebesar 24, diperoleh t tabel sebesar 2,064 pada a $5 \%$. Hasil tersebut menyatakan t hitung lebih besar dari t tabel. Sehingga $\mathrm{Ho}$ ditolak dan $\mathrm{Ha}$ diterima pada a $5 \%$ dan dapat ditarik kesimpulan bahwa "Ada pengaruh teknik relaksasi terhadap penurunan skala nyeri post operasi di rumah sakit Dr.Oen Solo Baru“.

\section{PEMBAHASAN}

Nyeri merupakan persepsi tidak nyaman secara fisik maupun psikologis yang terjadi akibat adanya injuri atau trauma sel dan jaringan yang aktual maupun potensial (Potter, 2005). Tindakan pembedahan merupakan tindakan medis yang dilakukan dengan mengiris atau menyayat jaringan untuk mengambil atau memperbaiki suatu jaringan tubuh yang ada di dalam tubuh. Walaupun pada awalnya tindakan ini dilakukan dengan pemberian obat anestesi, namun setelah efek obat anestesi tersebut hilang maka rasa sakit atau nyeri akibat adanya luka atau trauma jaringan akan muncul. Hasil penelitian menunjukkan bahwa seluruh responden merasakan nyeri mulai dari nyeri sedang sampai berat. Rasa nyeri pada post operasi adalah akibat peningkatan aktifitas sistem syaraf simpatis, perubahan tekanan darah, denyut jantung, warna kulit dan apabila tidak segera diatasi akan meningkatkan rasa khawatir, tegang, takut dan stress. Intervensi untuk mengurangi ketidaknyamanan atau nyeri selama post operasi yaitu intervensi farmakologis dan non farmakologis yaitu salah satunya menggunakan teknik relaksasi. (http://grahacendikia.wordpress.com)

Tindakan keperawatan untuk menurunkan nyeri sangat banyak. Relaksasi otot skeletal merupakan salah satu metode menurunkan nyeri dengan cara merilekskan ketegangan otot (Potter, 2005). Selain itu relaksasi juga merupakan salah satu manajemen nyeri non farmakologis atau non invasif untuk mengurangi nyeri yang dilakukan dengan melatih pasien melakukan napas dalam secara teratur sehingga membuat suplay oksigen ke jaringan memadai. (Priharjo, 1999). Pada penelitian ini tindakan melatih relaksasi dilakukan setelah pasien datang dari ruang operasi dan kesadaran sudah 
kompos mentis atau sadar penuh. Tindakan diajarkan satu kali sampai pasien bisa kemudian meminta pasien untuk mengulangi atau melakukan secara mandiri atau dibimbing keluarga pada saat merasakan nyeri. Setelah itu peneliti melakukan pengukuran skala nyeri.

Hasil penelitian menunjukkan terjadi penurunan nilai rata - rata skala nyeri dari skala 7,84 sebelum melakukan teknik relaksasi, menjadi 5,92 setelah melakukan teknik relaksasi. Hasil tersebut menunjukkan bahwa relaksasi efektif untuk menurunkan nyeri, karena hasil uji $t$ Test menunjukkan nilai $\mathrm{t}$ hitung $(7,855)$ lebih besar dari nilai t tabel yaitu 2 , 064. Dengan derajat kepercayaan 0,05 menunjukkan bahwa ada perbedaan nilai rata - rata sebelum dan sesudah pasien melakukan teknik relaksasi.

Menurut Tunner, seperti yang ditafsir oleh Potter (2005) relaksasi otot skeletal dipercaya dapat menurunkan nyeri dengan merilekskan ketegangan otot yang menunjang nyeri. Ada banyak bukti yang menunjukkan bahwa relaksasi efektif dalam meredakan nyeri. Beberapa penelitian telah menunjukkan bahwa relaksasi efektif dalam menurunkan nyeri pasca operasi. Ini mungkin karena relatif kecilnya otot-otot skeletal dalam nyeri pasca operatif atau kebutuhan pasien untuk melakukan teknik relaksasi tersebut agar efektif. Teknik tersebut tidak mungkin dipraktekkan jika hanya diajarkan sekali, segera sebelum operasi. Pasien yang sudah mengetahui tentang teknik relaksasi mungkin hanya diingatkan untuk menggunakan teknik tersebut untuk menurunkan atau mencegah meningkatnya nyeri.

Berdasarkan tabel 4 di atas didapatkan hasil sesudah teknik relaksasi yang dilakukan pada pasien post operasi yang paling banyak yaitu terjadi penurunan skala 19 (76\%). Namun demikian juga masih dijumpai pasien yang tidak mengalami penurunan skala nyeri atau skala nyerinya tetap (24\%). Rata-rata penurunan skala nyeri post operasi dikarenakan pasien yang kooperatif mengikuti bimbingan secara benar dan sesuai anjuran pembimbing. Adapun pada pasien yang tidak mengalami penurunan skala nyeri mungkin dikarenakan tidak melakukan teknik relaksasi dengan benar. Karena teknik relaksasi yang paling efektif terhadap nyeri ringan dan sedang, tidak efektif untuk nyeri berat.

Jika seseorang menerima input sensori yang berlebihan dapat menyebabkan terhambatnya impuls nyeri ke otak (nyeri berkurang atau tidak dirasakan oleh klien yang mengalami nyeri sedang). Stimulus yang menyenangkan dari luar juga dapat merangsang sekresi endorfin, sehingga stimulus nyeri yang dirasakan oleh klien menjadi berkurang. Peredaaan nyeri secara umum berhubungan langsung dengan partisipasi aktif individu, banyaknya modalitas sensori yang digunakan dan minat individu dalam stimulasi, oleh karena itu, stimulus penglihatan, pendengaran dan sentuhan mungkin akan lebih efektif dalam menurunkan nyeri dibanding stimulasi satu indera saja. (Tamsuri, 2007).

Relaksasi yang dilakukan dengan baik dapat meningkatkan asupan oksigen ke sel sehingga mencegah terjadinya metabolisme anaerob yang dapat meningkatkan produksi lactat. Dengan oksogen yang mencukupi maka produksi asam lactat menurun dan sensasi nyeri juga akan menurun. Dari uraian di atas dapat disimpulkan bahwa relaksasi yang dilakukan dengan baik dan teratur efektif untuk menurunkan skala nyeri pada pasien post operasi. 
KESIMPULAN DAN SARAN

1. Kesimpulan

Dari hasil penelitian yang telah dilakukan mengenai pengaruh teknik relaksasi terhadap penurunan skala nyeri post operasi di rumah sakit Dr.Oen Solo Baru, maka dapat disimpulkan sebagai berikut:

a. Pasien yang dapat menurunkan nyeri dengan teknik relaksasi sebanyak $76 \%$ dan yang tidak dapat menurunkan nyeri sebanyak $24 \%$.

b. Terjadi penurunan nilai ratarata skala nyeri sebesar 1,92 yaitu dari 7,94 menjadi 5,92

c. Teknik relaksasi berpengaruh secara signifikan untuk menurunkan skala nyeri pada pasien dengan tindakan operasi atau pembedahan (t hitung > t tabel)

2. Saran

Dari kesimpulan diatas dapat diketahui bahwa "ada pengaruh teknik relaksasi terhadap penurunan skala nyeri post operasi di rumah sakit Dr.Oen Solo Baru". Maka dari ini peneliti memberi saran pada:

a. Bagi rumah sakit

Disarankan agar menjadi pedoman untuk pemberian asuhan keperawatan terhadap pasien post operasi.

b. Bagi peneliti selanjutnya

Disarankan bagi peneliti berikutnya dapat meneliti teknik relaksasi dengan responden sebagai karakteristik yang memiliki rasa nyeri tapi bukan post operasi.

c. Bagi institusi pendidikan

Disarankan agar lebih memperdalam teknik relaksasi dalam mata kuliah dan diajarkan ke setiap mahasiswa untuk mencoba dan merasakan.

\section{DAFTAR PUSTAKA}

Hidayat, Aziz A. Riset Keperawatan dan Teknik Penulisan IImiah. Jakarta : Salemba Medika, 2003.
Nursalam dan Siti Pariani. Pendekatan Praktis Metodologi Riset Keperawatan. Jakarta : Sagung Seto, 2001.

Sugiyono. Statistik untuk Penelitian. Jawa Barat : Alfabete, 2005.

Mubarak, Wahit lqbul. Kebutuhan Dasar Manusia. Jakarta : EGC, 2007.

Robert, Priharjo. Perawatan NyeriPemenuhan Istirahat Pasien. Jakarta, 1999.

Potter, Patria A. Fundamental Of Nursing. Jakarta : EGC, 2005.

Tamsuri A. Konsep dan Penatalaksanaan Nyeri. Jakarta : EGC, 2007.

Ramali A. Kamus Kedokteran, Arti dan latilah. Jakarta : Djabatan, 2009.

Syaifuddin. Anatomi Fisiologi untuk Siswa Perawat. Jakarta : EGC, 1999.

Wuryanano. Berlatih Teknik Relaksasi. http://wuryanano.com/2007.

\begin{aligned} \hline 1 & Dosen AKPER Panti Kosala \\ & Surakarta \\ & Dosen AKPER Panti Kosala \\ & Surakarta \\ 3 & Dosen AKPER Panti Kosala \\ & Surakarta \end{aligned}

